\title{
Self-regulation of Mobile Marketing Aimed at Children: An Overview of the Spanish Case
}

\author{
María de Miguel Molina \\ Universidad Politécnica de Valencia (Valencia University of Technology) \\ Department of Management, mademi@omp.upv.es
}

Received 23 March 2007; received in revised form 27 September 2007; accepted 15 October 2007

\begin{abstract}
Mobile phones have changed consumer and company behaviour and today they constitute the most direct means of communication between them. Many groups are targeted through promotion campaigns using mobile phones. Children, who in the future will be the largest consumer of new technologies, are one of these groups. Given that current Spanish legislation does not clearly establish what company policy ought to be in relation to promotions aimed at children, self-regulation of the mobile telephone sector is imperative. Spain is already among the developed countries in which one out of every two children has a mobile phone. Firms should pay special attention to this target group. Firstly, because promotional campaigns aimed at children have their peculiarities and secondly because of the legal and ethical protection that children deserve. Company policy, in this sense, should include the drawing up of Codes of Conduct. This article begins by analysing the child segment as mobile phone consumers. It then highlights the legal and ethical problems of mobile campaigns aimed at children, and looks at some studies carried out by the European Commission and the Spanish government. Finally, this paper draws some conclusions about the measures companies should adopt and offers practical help for self-regulation of the mobile telephone sector in Spain and, if possible, in other countries (especially other European countries within the framework of the agreement signed by the leading European mobile operators in 2007 to develop self-regulatory codes by 2008). Moreover, future research needs to centre on whether these measures increase child protection.
\end{abstract}

Key words: Mobile marketing, Permission marketing, Corporate social responsibility, Selfregulation, Child safety and privacy 


\section{Introduction}

Mobile Marketing or M-Marketing is a direct marketing tool. It seeks personalised communication or dialogue with its target audience via the mobile phone. This medium allows users to interact with television programmes, download tunes and receive customised information, for example. It is becoming increasingly popular in promotion campaigns.

There are two strategies frequently used in promotions, known as push or pull strategies. The mobile phone opts mainly for a pull strategy as it publicises promotions via another medium (television, radio and packaging). This means it is the customers who initiate the relationship by sending a message to take part in the promotion [14]. Thus, a database of the consumer's tastes is created with the latter's prior consent. The current difficulties involved in obtaining a mobile telephone number database make this type of strategy more suitable.

Promotions via mobile phones are, however, much more profitable for the major mobile network operators - MNOs(in Spain: Movistar, Vodafone and Orange, and recently Yoigo-GSM) than for mobile virtual network operators MVNOs - (Carrefour, Happy Móvil and Euskaltel) or Mobile Service Firms (such as the members of AESAM, Association of Mobile Service Firms), since they retain over half the revenue [2], [32]. These major operators are also present in other different channels and manage their own information services (alerts, draws, logos, etc.).

Table 1: Mobile telephone sector in Spain [2], [32]

\begin{tabular}{|c|c|}
\hline Firms & $\begin{array}{l}\text { Revenue } 2006 \\
\text { (million euros) }\end{array}$ \\
\hline $\begin{array}{cl}\text { MNOs } & \\
\text { : } & \text { Movistar } \\
\text { - } & \text { Vodafone } \\
\text { - } & \text { Orange } \\
\end{array}$ & $\begin{aligned} & 13,390 \\
& 6,733.51 \\
& \text {. } 4,357.41 \\
& \text { - } 2,298.89 \\
& 0.19 \\
&\end{aligned}$ \\
\hline $\begin{array}{cl}\text { MVNOs } & \\
\text { - } & \text { Carrefour (Orange) } \\
\text { - } & \text { Happy Móvil (Orange) } \\
\text { - } & \text { Euskaltel (Vodafone) }\end{array}$ & $\begin{array}{ll}\text { n.a. } & \\
\text { - } & \text { n.a. } \\
\text { - } & 0.02\end{array}$ \\
\hline Mobile Service Firms & 400 (only AESAM) \\
\hline
\end{tabular}

However, Corporate Social Responsibility forces these companies to meet the needs of present and future stakeholders, thus going beyond legal requirements, by integrating the economic, social and environmental impact of an organisation's operations within the organisation's strategy [11].

Children are one of the profitable segments for mobile firms.

Table 2 : Mobile diffusion-base whole population 2006-2010 [9]

\begin{tabular}{|c|c|c|}
\hline Country & $\mathbf{2 0 0 6}$ & $\mathbf{2 0 1 0}$ \\
\hline Spain & 105 & 109 \\
\hline France & 76 & 85 \\
\hline Germany & 94 & 103 \\
\hline Italy & 117 & 122 \\
\hline United Kingdom & 109 & 113 \\
\hline
\end{tabular}

\section{The Mobile Phone Market in Spain}

The use of mobile phones for personal use has been growing exponentially in Spain since the 1990s, when the operator Moviline (Telefónica) began to offer this service.

In 2004, the Spanish National Statistics Institute (INE) estimated that $76.89 \%$ of Spanish homes had one or more mobile phones and the number of subscribers exceeded 37 million. 957,677 of those who had a mobile were children between 10 and 14 years of age. That is to say, one in every three children of this age had a mobile phone. In general, the use of mobile phones is greatest in the 16 - 24 age group. In $2006,88 \%$ of households had a mobile phone [24]. 


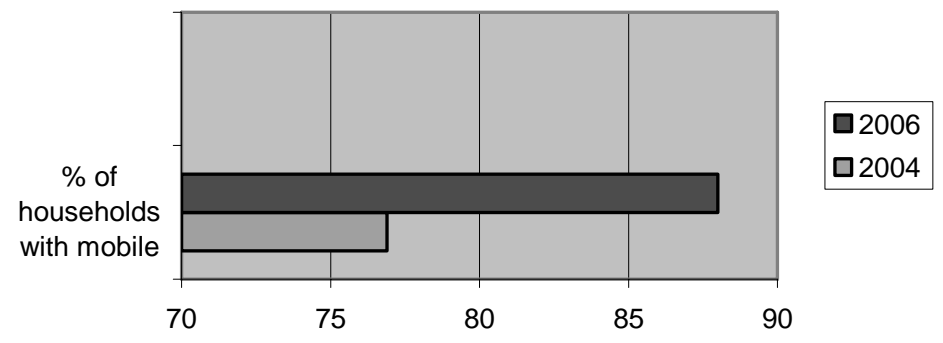

Figure 1: Percentage of Spanish homes with mobile phone, 2004-2006 [24]

$58 \%$ of children from 10 to 14 years of age have a mobile phone, i.e. currently one child in two has a mobile phone.

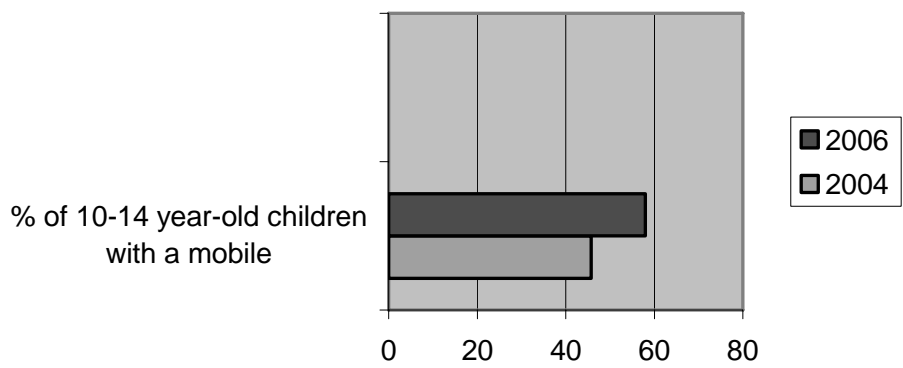

Figure 2: Percentage of children (10-14) in Spain with mobile phones, 2004-2006 [24]

The Mobinet Research 2005 survey [20], prepared by A.T. Kearney and Cambridge University, drew similar conclusions. The survey included 4,000 mobile users from 21 countries and confirmed positive growth in the demand for mobiles, particularly in the under-24s' group.

Children, as a target group, offer very interesting new business opportunities for companies. The mobile phone is with the consumer at all times, wherever he or she goes (unlike the Internet, for example). It is not a seasonal product and allows firms to establish a direct personal relationship with their customers [16].

It has been estimated that children are given their first mobile telephone when they are about eight or ten years old. Normally it is a present from their parents so they can check where their children are whilst the children feel safer and more protected. However, as far as children are concerned it is a toy, rather than a communications tool [17].

We could, in principle, consider all citizens under 18 years of age (according to article 315 of the Spanish Civil Code, and the Spanish National Statistics Institute) as children. However, the use of mobile phones in Spain is very limited amongst children under 10 [9].

\section{Methodology and Data}

The object of this analysis are children in Spain, from 10 to 17 years of age who use mobile phones. The present analysis aims to answer three major issues and to propose solutions for them:

- What are the problems mobile promotional campaigns cause in children?

- Why is the legal protection available not satisfactory?

- How can firms develop self-regulation?

The main objective of this article is to provide firms with the starting point/foundations to self-regulate their promotional campaigns in Spain according to legal and ethical principles.

To achieve this objective, an initial study of the Spanish market was carried out. Then information from secondary sources on the risks of mobile phones to children (Question 1) was compiled, Spanish legislation on the matter was analysed (Question 2) and current business initiatives underway and the scarce literature on the subject were examined (Question 3). Several papers on children's behaviour vis-à-vis mobile phones have been published [4], 
[16], [17] but few have looked into company self-regulation (they have studied this subject with reference to the Internet [21], [22], but not to mobile phones). A regulatory study allows us to identify and redefine the legal rules which exist in Spain and which thus may be used in the specific case of Mobile Marketing.

In addition to the INE data [24], the risks of mobile promotional campaigns for this target group in Spain are shown in two public studies carried out in Spain in 2005: a) a study commissioned by the Spanish Ombudsman for Children in the Madrid Region for the Protégeles Association (Protégeles = Protect Them) [28], and b) in an analysis of the relationship with ICT in the household by the Telecommunication and Information Society Observatory, which belongs to the public body Red.es [29].

Moreover, in 2006 the European Commission summarised the findings of a public consultation on child safety and mobile phones [10]. The consultation was based on a document and questionnaires which were structured around some of the major related issues, such as risks, regulatory framework, technical and European solutions. The main stakeholder groups were represented: industry actors, mobile network/virtual operators, software companies, content providers, media institutions and associations representing the industry, children's rights and welfare organisations, consumer organisations, environmental associations, different types of administrations -consumer, IT, media, police and regulators-, individual contributions and replies from researchers and the universities.

Table 3: Selected data for the first research question,

What are the problems mobile promotional campaigns cause in children?

\begin{tabular}{|c|c|c|c|c|}
\hline Study & Date & $\begin{array}{c}\text { Methodology } \\
\text { included }\end{array}$ & Respondents & Input \\
\hline Protégeles & 2005 & No & 2,000 individuals & $\begin{array}{c}\text { Behaviour of children } \\
11-14 \text { and risks in } \\
\text { Spain }\end{array}$ \\
\hline Red.es & 2004 & Yes & 7,423 individuals & $\begin{array}{c}\text { Behaviour of children } \\
10-14 \text { in Spain }\end{array}$ \\
\hline $\begin{array}{c}\text { European } \\
\text { Commission }\end{array}$ & 2006 & No & $\begin{array}{c}74 \text { (stakeholder } \\
\text { groups) }\end{array}$ & $\begin{array}{c}\text { Risks for European } \\
\text { children from child } \\
\text { safety and consumer } \\
\text { organisations' } \\
\text { perspective }\end{array}$ \\
\hline
\end{tabular}

Table 4: Selected data for the second research question,

Why is the legal protection available not satisfactory?

\begin{tabular}{|c|c|}
\hline Law & Input \\
\cline { 1 - 1 } Data Protection Act & \multirow{2}{*}{$\begin{array}{l}\text { Regulation of child } \\
\text { safety and privacy }\end{array}$} \\
\cline { 1 - 2 } Civil Code & \\
\cline { 1 - 2 } $\begin{array}{c}\text { Legal Protection of } \\
\text { Children Act }\end{array}$ & \\
\hline
\end{tabular}

Table 5: Selected data for the third research question, How can firms develop self-regulation? (A: Experiences)

\begin{tabular}{|c|c|}
\hline Experiences & Input \\
\hline AESAM Code & $\begin{array}{c}\text { Self-regulation of } \\
\text { child safety and } \\
\text { privacy }\end{array}$ \\
\hline $\begin{array}{c}\text { European agreement } \\
\text { and other documents }\end{array}$ & \\
\hline
\end{tabular}

To construct validity, several sources of evidence from prestigious institutions as well as participant observation [33] have been included. In any case, a future survey of our own is necessary to test whether the proposed measures are adequate. However, some of these sources also have their limitations as not all the studies have provided the research methodology used for Question 1 and thus we are unsure of the reliability of the answers. We can only check whether the results of the different studies are similar, irrespective of whether their methodology is included or not. 
Table 6: Selected data for the third research question,

How can firms develop self-regulation? (B: Literature)

\begin{tabular}{|c|c|c|}
\hline $\begin{array}{c}\text { Literature (Books and Business } \\
\text { Source Premier Database) }\end{array}$ & Date & Input \\
\hline Mason, R.O. et al. & 1995 & Ethics and privacy \\
\hline Kerckhove, A. & 2002 & Children as mobile consumers \\
\hline Nairn, A. and Berthon, P. & 2003 & Self-regulation (Internet) \\
\hline Barnes, S.J. and Scomavacca, E. & 2004 & Mobile Marketing and permission \\
\hline Moor, J.H. in Bynum and Rogerson & 2004 & Ethics and data \\
\hline Moore, E.S. & 2004 & Self-regulation (Internet) \\
\hline Newman, A. and Bach, D. & 2004 & Self-regulation in Europe \\
\hline Sipior, J. et al. & 2004 & Ethics and data \\
\hline Jenkins, F. & 2006 & Protection of children in other countries \\
\hline Nairn, A. & 2006 & Self-regulation in other countries \\
\hline
\end{tabular}

\section{Problems that Mobile Promotional Campaigns Cause in Children}

\subsection{Study: 'Child Safety and Habits in the Use of Mobile Telephones', Protégeles Association}

The study commissioned by the Spanish Ombudsman for Children in the Madrid Region for the Protégeles Association (May 2005) on the mobile telephone habits of children in this region was based on a survey of 2,000 children carried out in schools and outdoor recreational areas. The children and adolescents interviewed were between 11 and 17 years of age and were of both sexes. [The results corresponding to children between 11 and 14 years of age are the ones that have been used here]. Although no methodology has been provided, this study can be taken as a starting point (with the limitations detailed above) as it has already been used as a reference in several national and EU studies [10].

The most important conclusions drawn from this study were [28]:

- $\quad$ Child expenditure was not exorbitant, but one in every four who had a mobile spent most of his/her pocket money on his/her phone: $18 \%$ spent between $€ 20$ and $€ 40$ a month, and $7 \%$ spent over $€ 40$ a month.

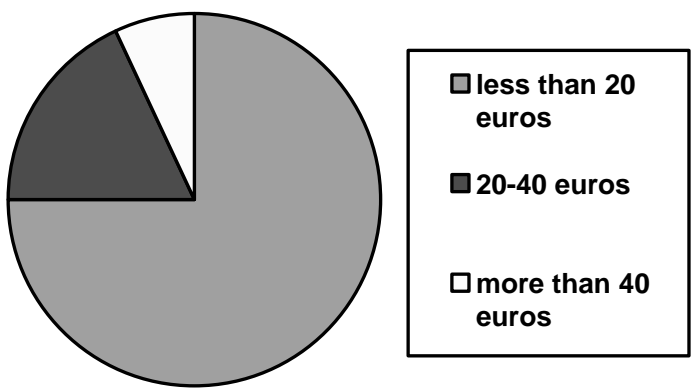

Figure 3: Child expenditure (monthly) [28]

- $\quad$ Most also spent part of their money on the purchase of mobile associated products such as tunes, logos or backgrounds, games, etc. $77 \%$ had acquired tunes and tones for their mobile and $68 \%$ backgrounds or logos.

- $69 \%$ used pre-payment systems rather than contracts.

- Sexual harassment through mobiles is very recent, and therefore of low intensity. However, we should be aware that $18 \%$ of children with a mobile have already felt harassed in this sense.

- $\quad$ The reception of unsolicited messages, i.e. a similar phenomenon to spam on the Internet, has spread more rapidly. $68 \%$ of children had received them. Among these, the most worrying are incitements to gambling, draws, etc.

- It is worrying to find that of the $14 \%$ who chat using their mobile, half had done so with strangers. 
- The great majority of children who had received photographs on their mobile exchanged photographs of friends, but $9 \%$ also said they had received pornographic images.

- $\quad 38 \%$ of children said they became restless and even anxious when forced to do without their mobiles. $11 \%$ said that they had lied to their parents and had, on some occasions, even stolen money to top-up their mobiles.

Thus, we can say that some children spend quite a lot of money per month on their mobile and have access to unsolicited and/or inappropriate content through their mobiles.

\subsection{Report by Red.es, 'Childhood and Adolescence in the Information Society'}

This government report gathered data obtained between July and September 2004 from a representative sample of 3,178 households and 7,423 individuals of 10 years and over, located in the Spanish mainland and the Balearic and Canary Islands. These samples had errors of $+1.96 \%$ for households and $+1.27 \%$ for individuals. A simple random sample was $\mathrm{p}=\mathrm{q}=0.5$ and had a validity of $95.5 \%$.

The report analysed children's and young people's (up to 18) relationship with information and communication technologies. As it segmented households with children by different age ranges, this analysis has used the segment closest to that of children from 10 to 14 years of age, which can be said to have greater risks.

This Report confirmed that [29]:

- The mobile is an everyday communication tool which has increasingly been incorporated into all sectors of society, and especially among children and young people. Children like to try out new technological inventions; they are not 'frightened' of experimenting with them.

- $\quad 50.6 \%$ of children between 10 and 15 years of age had a mobile and 31\% said they used it daily. In fact, $91.5 \%$ of households with children from 6 to 15 years used a mobile phone.

\subsection{European Commission, 'Findings from the Public Consultation on Safer Mobile Use'}

This study [10] was based on asking the major stakeholder groups: Mobile network/virtual network operators, software companies, content providers, media institutions and associations representing the industry, children's rights and welfare organisations, consumer organisations, environmental associations and different types of administrations about child safety and mobile services. There were also some individual contributions, replies from researchers and universities. Apart from child safety, most contributions from consumer organisations and some of the child safety organisations stress risks relating to mis-contracting with children, access to chargeable content, fraud and spam. Many of these contributions mention that with mobile phones becoming credit cards, children become contracting partners, who can buy ring tones, logos and interactive games and take part in TV games, but also buy products on the Internet. They stress that children are particularly vulnerable to fraud and unfair commercial practices. Consumer organisations also stress the risk of high expenditure through some premium rate services which do not have transparent pricing schemes or are difficult to stop (although part of this risk is mitigated in some countries by self-regulatory measures). Some children do not tell their parents if they have their mobile stolen, therefore the subscription is not frozen immediately.

Exposure and access to illegal/harmful/adult content also ranks high among the risks identified. This general item covers various types of content. As far as commercial content is concerned, some MNOs and service providers argue that thanks to the tools already in place the risk to accessing harmful content when using an MNO's portal services is actually very limited. However, child safety organisations state that there have been cases of children ordering premium rate services with sexual content or receiving ads for it and that age verification systems do not always exist. MNOs stress that restricted access to adult content on mobile phones has not been called for in all national markets. Illegal content can be accessed through the Internet. Types of harmful content include pornography and violence. Many contributions, especially from MNOs, stress that the perception of what is harmful is culture-specific and varies from one country to another.

\subsection{Public Study Conclusions}

The three studies analysed detail the risks to children that mobile telephones entail, i.e. Question 1 . We can conclude that the studies highlight several problems, such as sexual harassment, spam, chatting with strangers, pornographic images received, anxiety and mis-contracting. The most frequent problem is spam. 
Based on these conclusions, a regulatory study has been carried out to find out how Spanish legislation protects children from these supposed invasions of their privacy and their lack of maturity.

\section{Spanish Legislation}

Reality shows us that children already use mobile phones (at least from 8 years onwards) and for this reason specific regulations are required to protect them. But why is the legal protection available not satisfactory? (second research question).

According to Negroponte [25], in this new post-information era the audience is sometimes only one person. 'Everything is done to order and information is personalized to the maximum. It is assumed that individualization is the extrapolation of selective transmission: from a large group to a small one, then to a smaller one and finally to the individual. Once they have our address, marital status, age, income, make of car, purchases, drinking habits and taxes, they've got us: we are a one-person demographic unit'. And that unit may be an adult or a child.

Users must "beware" as Sipior, Burke and Rongione [31] warn. However, it is also necessary for firms to regulate this and for the government to act. Moor [6] speaks of the need for a security principle so that the rules and conditions that regulate private situations are clear and known by the people they affect.

Promotions aimed at children through the media may arouse not only legal but also ethical issues. In general, anybody under 18 could be classed as a 'child' but this age limit cannot always be so strict. For example, targeting a child with a simple information campaign is not the same as inducing him/her to buy, or asking for personal details in order to send him/her a gift is not the same as subscribing him/her to a publication.

In the face of these issues, the Data Protection Agency [8] has clarified and explained at what age we can consider that legal children are mature enough to give their consent and at which age this consent must be given with that of their legal representative.

Spanish law attributes the capacity to undertake certain legal acts to persons over 14 years of age. Article 162.1 of the Civil Code exempts 'acts referring to the rights of the personality or others that the child, in accordance with the laws and with his or her conditions of maturity, can carry out for him or herself ' from legal representation. Therefore, in the case of children over 14 years old, a child is considered to be sufficiently mature to give consent to the simple processing of his or her data (provided it has been given with all the legal guarantees and for services appropriate to his or her age).

The Directorate-General of Registries and Notaries, in its resolution of 3rd March 1989, indicated that 'There is no rule that expressly declares their incapacity to act validly in civil matters'. Therefore, being under 18 is not a cause of incapacitation (of the causes regulated under the Civil Code), and has to be analysed in each specific case for the purposes of gauging maturity in the giving of consent.

Furthermore, according to article 4.3 of Act 1/1996 of 15th January, on the Legal Protection of Children, 'any use of a child's image or name in the media that may be detrimental to his/her honour or reputation, or that may be contrary to his/her interests, is considered an illegitimate intromission in the right to his/her honour, to personal and family privacy, and to the child's own image, even if the child or his/her legal representatives have given their consent'. Thus, this article offers the suggestion that it may have been the child him/herself who has consented to the use of his/her own image, without requiring the presence of his/her legal representative, provided that it does not injure his or her honour or reputation or is not contrary to his/her interests.

Consequently, children over 14 years of age are mature enough to be able to consent, by themselves, to the automated processing of their personal data. The same cannot be said of other children, so the reference must be sought in article 162.1 of the Civil Code, basically taking into account their maturity. In the case of children under 14 years old whose maturity does not guarantee full understanding by them of the consent given, the consent of their legal representatives will be essential.

An example of this is the case of e-commerce in the USA. In 1998, the Federal Trade Commission developed the Children's Online Privacy Protection Act (COPPA) which requires the Commission to enact rules governing the online collection of personal information from children under 13 (2000). Firms have to make any reasonable effort (taking into consideration the available technology) to ensure that before personal information is collected from a child, one of the child's parents receives notice of the operator's information practices and consents to those practices [7]. Obviously this measure does not totally guarantee that an individual using any online technology is of a specific age but at least it is good practice which tells both adults and children whether the content they wish to access is suitable for their age group.

On the other hand, article 5 of the aforementioned Legal Protection of Children Act affirms that children are entitled to seek, receive and use information appropriate to their development. Parents or guardians and the public powers will be vigilant that the information received by children is truthful, plural and respectful of constitutional principles. 
Special rules can be implemented to guarantee that the publicity or messages aimed at children or broadcast in programmes aimed at them does not harm them morally or physically.

Without prejudice to other legitimated persons, it is the responsibility of the Public Prosecutor and the competent authorities in matters of child protection to act to remove and rectify any illicit publicity.

The issue, however, arises in the case of promotions that do not consist of a simple gathering of data, but incite the child to buy or to spend a certain amount of money.

In short, Spanish legislation protects children via the following regulations:

Table 7: Spanish regulations on child privacy (which can be applied to mobile services)

\begin{tabular}{|l|l|}
\hline \multicolumn{1}{|c|}{ Regulation } & \multicolumn{1}{|c|}{ Law } \\
\hline $\begin{array}{l}\text { Child up to 14 who is not mature needs the } \\
\text { permission of his/her legal representative to give } \\
\text { his/her data }\end{array}$ & $\begin{array}{l}\text { Data Protection Act } \\
\text { Civil Code } \\
\text { Legal Protection of Children Act }\end{array}$ \\
\hline $\begin{array}{l}\text { Child up to 16 needs the permission of his/her } \\
\text { legal representative to make purchases or to } \\
\text { access means of payment and from 16 to 18 } \\
\text { depends on maturity. }\end{array}$ & Civil Code \\
\hline $\begin{array}{l}\text { Only permits access to services appropriate to } \\
\text { their age, up to } 18 \text { years }\end{array}$ & Legal Protection of Children Act \\
\hline
\end{tabular}

In these cases, as the law is not always clear (maturity, appropriate, even "disbursements", are vague concepts), it would be advisable for firms to have Codes of Conduct that make their policy towards children clear.

\section{Self-regulation and Entrepreneurial Actions}

For this purpose, a code of ethics can be a system of rules or guidelines, put forward by the top echelons of a company to clarify these legal measures and other more specific measures to ensure the mobile phone industry protects children.

Mason [18] identified four major ethical themes in the information era: privacy, freedom from errors, ownership and accessibility. Nowadays, however, this list is incomplete. Bynum and Rogerson [6] note that a code of ethics for computer professionals may fulfil various functions: to inspire the conduct of professionals, educate them, guide them, place a minimum and a maximum limit to their responsibility and care, and reinforce firms' or freelance professionals' reputation.

Both the 1999 Data Protection Act and the 2002 Information Society Services Act refer to the need for firms to establish their own Codes of Conduct or what the latter call 'Type Codes'.

The European Union also wants to encourage these Codes of Conduct. Thus in 2004, the European Parliament and Council began to work on a 'Recommendation on the Protection of Minors and Human Dignity and on the Right of Reply in relation to the competitiveness of the European audiovisual and on-line information services industry' (now on second review, COM (2006) 546 final. 2004/0117 (COD). 21.9.2006) [12].

It is affirmed that the member states must make the professionals, intermediaries and users of the new media responsible for, among other measures, drawing up a code of conduct in collaboration with the professionals and regulatory authorities at national and European levels. However, it is considered that the self-regulation of the audiovisual sector constitutes an effective additional, but not sufficient, means of protecting children against messages with harmful content [12].

Some authors [26] believe the European administration takes the sector involved much more heavily into account than the North American administration when considering self-regulation, although this may make it less effective. 'Self-regulation in the shadow of American public power features a more active judiciary and regular involvement by quasi-autonomous regulatory agencies. An engaged, facilitative executive and occasional formal legislation, by contrast, characterize comparable industry self-regulation in the EU'.

In Spain, the Association of Mobile Service Firms (AESAM) which groups together firms such as Lanetro, Movilisto, Myalert or Netsize, possesses its own Code of Conduct for member firms [1], which promotes the self-regulation of the sector. This Code of Conduct has been in force since 2006, even though some reforms were introduced in July 2007 such as implementing a Trust Seal for members who comply with the Code, the creation of a Self-Enforcement Committee and the implementation of an internal disciplinary regime. 
In this Code of Conduct, we can highlight Chapter I (Section III), dedicated to services for children (something not normally reflected in other Codes of Conduct):

- Services for children are considered to be all those that, both wholly and partly, are aimed specifically at persons under 18 years of age. Any service promoted through a children's or juvenile publication is understood to be aimed at these persons, as well as any other that by virtue of its target audience is clearly attributable to this age group.

- Such services must not:

1. Make reference to violence, sexuality, racism or any other subjects that could be considered inappropriate for the young people the service targets

2. Use vocabulary that alludes to the abovementioned aspects or that might be considered bad taste

3. Contain materials or contents that may be mentally or morally harmful, or exploit their credulity, lack of experience or sense of legality

4. Involve an invasion of the child's privacy

5. Encourage excessive use of higher-rate mobile services, promote compulsive consumption of products or deliberately create any type of addiction to this type of services

- The parents, guardians or legal representatives of children will be responsible for the use made by the latter of mobile phones.

- The providers of services to mobiles will use, as far as possible, the mechanisms necessary to verify the age of the users of certain mobile services. They will furthermore employ, as far as possible, the necessary mechanisms to obtain the acceptance or the express permission of the parents, guardians or legal representatives of the children for the latter to access services not specifically intended for them. For example, we have found that some mobile service firms do not take any measures to verify the age of the consumer. We can buy the following picture simply by sending an SMS:

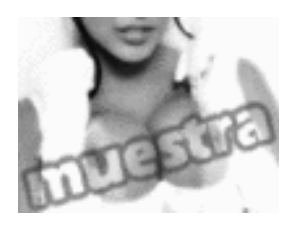

Figure 4: Picture offered by a mobile service firm

- As well as children, this Code expressly mentions disabled persons, especially the mentally disabled. Services which are specifically aimed at this type of group will be subjected to prior vetting by the corresponding representative associations or federations at national level.

With regard to the ethical performance of firms in their campaigns, article 27 of the AESAM Code of Conduct sets out the conditions that must be met by advertisements for promotions, sales or rentals, made via messages using a mobile. They include the following: They must:

1. Be aimed directly at persons who have the legal capacity to enter into a contract

2. Not be aimed directly at persons under 18 years of age

3. Not contain direct appeals to children to compulsively purchase a product or service

Thus we can find campaigns for alcoholic drinks (e.g. J\&B) in which the participant is asked his or her age, and if the answer is less than 18 years, s/he is told that s/he cannot take part in the promotion. The problem is how the firm can find out whether the person at the other end of the message is telling the truth, and if they are not, whether they must identify themselves when collecting the prize they have won.

Any consumer who receives a message must have given their consent to, or at least shown an explicit interest in, receiving such messages (in Spain this is a requirement of the 1999 Data Protection Act and the 2002 Information Society Services Act). This has been described as Permission Marketing or the obtaining of the express permission of the actual/potential customer in order to establish a relationship with him or her [3]. As we shall see, the legal requirements are stricter when requesting a child's personal details. 
In 2005, Telefónica Móviles (Movistar) launched a promotion for children, adapted to the communication needs between parents and children and to the demands for safety and saving for the little ones. The package consisted of a mobile phone and a series of services aimed at encouraging children to use their mobile responsibly: restriction of calls, text messages and multimedia messages, localisation service, reverse charge calls, educational games and restricted access to adult content on the web service. The product had the 'for responsible consumption' backing of the Spanish Consumers Union (UCE), and included a sticker to the effect on the product packaging. Telefónica Móviles Spain has a collaboration agreement with the UCE to improve citizen information about mobile telephones, to protect their rights and to seek solutions to improve services, applications and mobile contents.

Nowadays many firms, such as the Spanish toy manufacturer Imaginarium (Mo1 mobile phone), are offering special devices aimed at children.

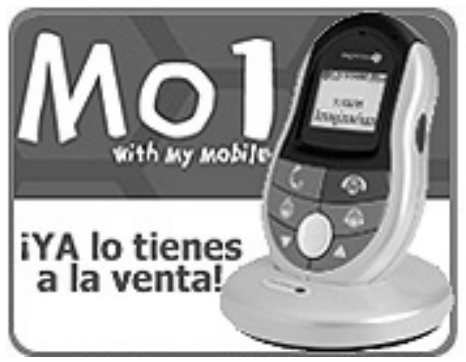

Figure 5: Imaginarium mobile for children

Source: www.imaginarium.es. Printed with permission

However, the best global self-regulation is derived from the agreement signed by leading European mobile operators in Brussels in February 2007 on how to protect children who use mobile phones. In this agreement, mobile operators undertook to develop self-regulatory codes by February 2008. Its efficiency will be monitored and assessed by the Commission after 12 months [13]. This agreement, brokered by the European Commission, responds to the findings of the Commission's public consultation on child safety and mobile phones [10].

These self-regulatory codes must be similar across Europe, even though there may be different legislation in force. For example, in other European countries data about children can be gathered if they are over 12 years of age [15].

All respondents agree that the responsibility for children's safe use of mobile phones should be shared between parents and carers, the industry (MNOs, MVNOs and service providers) and the public authorities. Most firms consider that their main responsibility is to protect children from access to commercially inappropriate content by providing parents with information and parental control tools and implementing content classification.

Self-regulation is seen as potentially the most appropriate way to ensure child protection due to the rapidly changing technical environment, but self-regulation still needs to be launched or effectively implemented in some countries. Through their European association GSME (Groupe Speciale Mobile Europe), MNOs have proposed the "development of an EU-wide common framework for national self-regulation". There is general support for the creation of a platform for exchanging best practices at European level, which should be supported by the EC.

In countries where specific regulation exists and where co- and self-regulation agreements have been reached (Denmark, Italy, Belgium, France, the UK, Germany, Finland, Ireland, Malta, the Netherlands, Poland and Sweden), the general feedback is that it is effective and well-balanced, even if some NGOs point to a need for reinforcing or improved monitoring of self-regulation in Belgium, the Netherlands, Finland, Poland, Italy and the UK (for location services). Self-regulation is required in Greece, Hungary, the Czech Republic, and more general regulation in Lithuania, Slovenia and Poland.

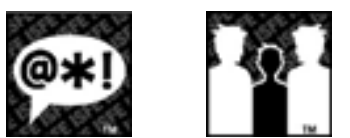

Bad language Discrimination

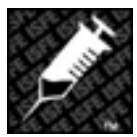

Drugs

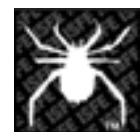

Fear

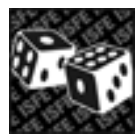

Gambling

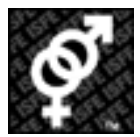

Sex

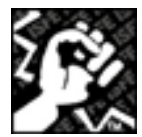

Violence

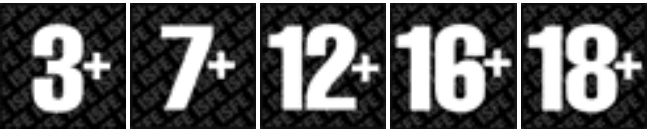

Figure 6: PEGI pictograms, content types and age categories

Source: www.pegi.info. Printed with permission 
There is a wide consensus among NGOs, MNOs and content providers that commercial content needs to be classified. An age and thematic classification, such as the PEGI (Pan-European Game Information) Code could be used (see Figure 6).

The industry agreement signed in 2007 is a result of discussions held between a high-level group representing mobile operators, content providers, child protection and consumer organisations, and regulators and responds to many of the concerns expressed in replies to the Commission's public consultation on safer mobile use. The operators agreed to support:

- $\quad$ Access control for adult content;

- $\quad$ Awareness-raising campaigns for parents and children;

- Classification of commercial content according to national standards of decency and appropriateness;

- $\quad$ The fight against illegal content on mobiles.

The signatories were Bouygues Telecom, Cosmote, Debitel AG, Deutsche Telekom Group, Go Mobile, Hutchison 3G Europe, Jamba! GmbH, Mobile Entertainment Forum, Orange Group, Royal KPN N.V., SFR, Telecom Italia S.p.A, Telefonica Moviles, S.A., Telenor, TeliaSonera and Vodafone Limited. As we can see, the three major operators located in Spain are included in this list.

In 2004, the Mobile Joint Code of Practice was adopted in the UK by mobile phone operators. This was considered as a major step forward in protecting children from paedophiles and pornography on the Internet [23]. The aim of the code is to provide a basic common framework. The key points of the Code include a rating for adult content for which an independent classification body is appointed to provide a framework for the classification of commercial content unsuitable for those under 18; an age verification procedure before such content is distributed to a customer; an independent classification framework similar to that used in the media industry; monitoring of chat rooms; parental controls to be added to devices; and greater cooperation between mobile operators and law enforcement agencies.

\section{Discussion}

There are many problems and risks that mobile promotional campaigns in Spain (and other countries) cause in children as we have pointed out in this paper. Legal protection is available, but it is quite vague. Self-regulation is imperative, such as the project the European Commission is developing with the EU's major operators. Yet selfregulation also needs to be controlled by the public authorities (a look at several magazines has demonstrated that some AESAM firms do not implement their code of conduct).

In Spain, both the 1999 Data Protection Act and the 2002 Information Society Services Act refer to the need for firms to establish their own Codes of Conduct or what the latter call 'Type Codes'. Despite this, legal protection of children as customers needs to be reinforced, especially when using mobile phones.

When developing these Codes of Conduct for Mobile Marketing promotion for under-18s (third research question, How can firms develop self-regulation?), this article suggests firms should adopt the following four measures (based on the existing legislation shown in the regulations analysed here):

Table 8: Measures based on Spanish regulation when developing

Codes of Conduct for Mobile Marketing promotion for under-18s

\begin{tabular}{|l|l|}
\hline \multicolumn{1}{|c|}{ Measures } & \multicolumn{1}{|c|}{ Regulation } \\
\hline $\begin{array}{l}\text { Ensure that any child up to 14 has the permission of } \\
\text { his/her legal representative to give his/her data }\end{array}$ & $\begin{array}{l}\text { Data Protection Act } \\
\text { Civil Code } \\
\text { Legal Protection of Children Act }\end{array}$ \\
\hline $\begin{array}{l}\text { Ensure that any child up to 18 has the permission of } \\
\text { his/her legal representative to make purchases or to } \\
\text { access means of payment }\end{array}$ & Civil Code \\
\hline $\begin{array}{l}\text { Permit small disbursements from 14 years of age } \\
\text { onwards, provided that the services lower their } \\
\text { prices and never charge for a message at } € 1.2, \text { but } \\
\text { at } € 0.15 \text { (when only data is requested) and a } \\
\text { maximum of } € 0.30 \text { or } € 0.50 \text { (when that small } \\
\text { disbursement is requested). }\end{array}$ & Civil Code \\
\hline $\begin{array}{l}\text { In all cases, only permit access to services } \\
\text { appropriate to their age, up to 18 years }\end{array}$ & \\
\hline
\end{tabular}


To minimise the risks mentioned, it would be useful if firms also implemented the following processes [10]:

- $\quad$ Age verification, both for pre-paid and post-paid cards. For example, face-to-face age verification is required by law in Germany. Other ways to check age are usually through credit cards. However, many MNOs stress the difficulty in implementation and the high costs incurred.

- Filtering and blocking systems. Norway and UK have implemented blocking of illegal web sites (by ISPS including mobile operators).

- Dedicated mobile phone packs for the younger age groups.

- $\quad$ Setting a ceiling amount for mobile phone subscription.

- $\quad$ Registering when you buy a pre-pay card (to indicate that it is for a child).

The creation of a platform for exchanging best practices at European level, supported by the EC, would be useful for exploring solutions on a European scale:

- Subject-based classification scheme at European level (similar to PEGI) could improve efficiency and transparency.

- Assistance with the development of common standards for mobile-based Internet filtering tools, alternatives to blocking Internet.

- $\quad$ Creation of a quality standard.

To raise awareness of firms and consumers, the government will need:

- $\quad$ To develop preventive campaigns for children aimed at transmitting the need to make proper use of mobile phones.

- To carry out campaigns aimed at the family and school environments, to make parents and educators sensitive to the need to transmit a series of basic safety regulations to children.

- To reach agreements with mobile telephone operators operating in Spain, for them to include filtering services and parental involvement. Such systems have already been developed in other countries, such as the UK, and include preventing pornographic photographs from being downloaded, restricting the sending and receiving of SMS or MMS depending on times or days, rejecting undesirable SMS, preventing purchases, voting in competitions, etc.

Preventive work should be developed both at educational level, sensitizing children, parents and educators to make proper use of ICT, and at a technological level, collaborating with mobile telephone operators, so that families are available to prevent these situations from happening.

All this involves measures of verification which may perhaps detract from the immediacy of a promotion, but which firms must take into account if they wish to avoid legal problems with child representatives or certain consumer associations.

The proposed measures, based on Spanish legislation and business practice, may serve as a starting point to create a self-regulatory code in Spain as requested by the European Union. It could also be used as a guideline for other EU countries. Currently, the only code in force is the AESAM Code, which although it is a commitment acquired by companies was not created in conjunction with the government (although the Consumers' Association was involved) and despite the recent changes it has introduced there is still room for additional child-related measures, such as those put forward in this paper.

\section{Conclusion}

As we have seen in this paper, children are a very attractive market segment for mobile telephone firms, since they are consumers who are familiar with and use new technologies from a very early age. For this reason, and given that current Spanish legislation does not clearly establish company policy in relation to promotions aimed at children, selfregulation of the mobile telephone sector is imperative.

Children are not sufficiently protected against different types of risks relating to mis-contracting, access to chargeable content, fraud and spam. Children become contracting partners, who can buy ring tones, logos and interactive games and take part in TV games, but also buy products over the Internet. Children are particularly 
vulnerable to fraud, unfair commercial practices and high expenditure through some premium-rate services which do not have transparent pricing schemes, or are difficult to stop.

Under the Spanish Civil Code, being under 18 does not disqualify children from entering into a contract and has to be analysed in each specific case to gauge the maturity in the giving of consent, (i.e. it is not clear when a child can or cannot contract).

The business associations of some service providers, such as the AESAM in Spain, have realised the importance of self-regulation but not all mobile service firms have signed the AESAM Code of Conduct (which in any case should be much more specific and not just copying out the law). At least the last European agreement has been signed by the three major operators in Spain and should be up and running by February 2008.

Nevertheless, this study has its limitations. The main factor is that it focuses on Spain and thus the information provided relates mainly to the Spanish case. However, as we have seen, the European Commission's desire is that the development of a European space in audiovisual matters, based on freedom of expression and respect for citizens' rights, should be based on continuous dialogue among national and European legislators, the regulatory authorities, industry, associations, citizens and society in general. With this in mind, this paper may be a good starting point for other European countries.

In addition, the information which relates Mobile Marketing to children and industry self-regulation, especially if we are talking about Spain, is currently very limited. Literature on the subject is scarce, as it tends to centre on children's behaviour as mobile phone users [4], [16], [17] and not on the existing risks or on the industry's selfregulation. We must also add to this the fact that there are few studies available on the subject and not all of them provide research methodology [10], [28], [29]. Nevertheless credit is due as these are pioneering studies on these issues in Spain and they speak out about a reality which often goes unnoticed. Television [5], [19], [27], [30] or Internet [21], [22] are well used and known but mobile phones, which are closer and more readily available, are still not seen as a threat to privacy and safety.

In further research, to complete this case study [33], we could test if the measures proposed in this article have been useful in improving child protection. A future survey of our own is necessary to test whether the measures proposed are adequate. However, we would first need to enlist companies which were prepared to implement these measures. On the other hand, children's answers may not be entirely reliable as children under 14 must be interviewed with their parents' consent and their parents must be present if they insist on being there. This means that the children's answers may be conditioned by the fact that their parents are there. It would perhaps be more advisable to carry out in-depth interviews with children whose parents allow them to be consulted without them being there.

\section{Acknowledgments}

I would like to thank Professor Lorenzo Cotino (University of Valencia, Faculty of Law) for his helpful comments and for the financial support received from the 'Protection of consumers and users in the ICT Society' research project (Generalitat Valenciana, reference GV05/241).

\section{References}

[1] Association of Mobile Services Firms, AESAM (2007). Code of Conduct. [Online]. Available: www.aesam.org/images/c\%C3\%B3digo\%20de\%20conducta\%20de\%20aesam-dic05 modificado-jul07.pdf

[2] Association of Mobile Services Firms, AESAM (2007). Firms Members. [Online]. Available: www.aesam.org/index.php?option=com content\&task=view\&id=3\&ltemid=10

[3] S.J. Barnes and E. Scomavacca, Mobile marketing: the role of permission and acceptance, International Journal of Mobile Communications, vol. 2, no. 2, p. 1, 2004.

[4] E. Bigné, C. Ruiz and S. Sanz, Key Drivers of Mobile Commerce Adoption. An Exploratory Study of Spanish Mobile Users, Journal of Theoretical and Applied Electronic Commerce Research, vol. 2, no. 2, pp. 48-60, 2007.

[5] M. Brucks, G.M. Amstrong and M.E. Golberg, Children's use of cognitive defenses against television advertising: a cognitive response approach, Journal of Consumer Research, vol. 14, pp. 471-482, 1988.

[6] T.W. Bynum and S. Rogerson, Computer Ethics and Professional Responsibility, 1st ed. Blackwell Publishing, 2004.

[7] Children's Online Privacy Protection Act, COPPA (2000). Federal Trade Commission USA. [Online]. Available: http://www.ftc.gov/bcp/conline/pubs/buspubs/coppa.htm

[8] Data Protection Agency of Spain (2007). [Online]. Available: www.agpd.es

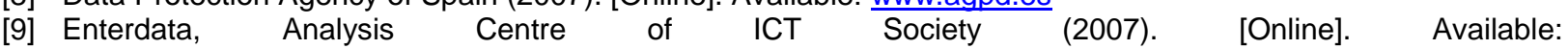
http://www.enter.es/buscador/enterdata.html?id=96

[10] European Commission. Information Society and Media Directorate-General (2006). Summary of the results of the public consultation "Child safety and mobile phone services", findings from the public consultation on safer mobile use. [Online]. Available: http://europa.eu.int/information society/activities/sip/public consultation 
[11] European Foundation for Quality Management (EFQM), The EFQM Framework for Corporate Social Responsibility, Brussels: EFQM, 2003.

[12] European Commission. Recommendation on the Protection of Minors and Human Dignity and on the Right of Reply in relation to the competitiveness of the European audiovisual and on-line information services industry (second review). Reference: COM (2006) 546 final, 2004/0117 (COD). [Online]. Available: http://eurlex.europa.eu/LexUriServ/site/es/com/2006/com2006 0546es01.pdf

[13] European Union Press Releases (2007). Safer Internet and the framework agreement on "Safer Mobile Use by Younger Teenagers and Children". Reference: IP/07/139. [Online]. Available: http://europa.eu.int/saferinternet

[14] M. Haig, Mobile Marketing. The Message Revolution, 2nd ed. London: Kogan Page, 2002.

[15] F. Jenkins, Mobile marketing, Young Consumers, vol. 7, no. 2, pp. 60-63, 2006.

[16] A.D. Kerckhove, Mobile Marketing must have acknowledgement, Precision Marketing, vol. 14, no. 149, pp. 14$15,2002$.

[17] A. Kerckhove, Building brand dialogue with mobile marketing, Young Consumers, vol. 3, no. 4, pp. 37-42, 2002.

[18] R. O. Mason, F.M. Mason and M.J. Culman, Ethics of information management, 1st ed. Thousand Oaks, CA: Sage Publications, 1995.

[19] R.A. Mendelson, The commercialisation of children's television, Pediatrics, vol. 89, no. 2, pp. 343-344, 1992

[20] Mobinet Study 2005 (2006). [Online]. Available: http://www.atkearney.com/main.taf?p=5,3,1,121,1

[21] E.S. Moore, Children and the changing world of advertising, Journal of Business Ethics, no. 52, pp. 161-167, 2004.

[22] A. Nairn and P. Berthon, Creating the customer: the influence of advertising on consumer market segments Evidence and Ethics, Journal of Business Ethics, no. 42, pp. 83-99, 2003.

[23] A. Nairn, Mobile phones and the internet: Legal issues in the protection of children, International Review of Law, Computers \& Technology, vol. 20, no. 1/2, pp. 177-185, 2006.

[24] National Institute of Statistics (INE, Spain) (2007). Use of ITC in the Households, Surveys 2004, 2005 and 2006. [Online]. Available: http://www.ine.es/inebase/cgi/um?M=\%2Ft25\%2Fp450\&O=inebase\&N=\&L

[25] N. Negroponte, How to succeed digital revolution, ExpoManagement, no. 6, pp. 1-7, 2003.

[26] A. L. Newman and D. Bach, Self-Regulatory Trajectories in the Shadow of Public Power: Resolving Digital Dilemmas in Europe and the United States, Governance, vol. 17, no. 3, pp. 387-413, 2004.

[27] R.T. Peterson, The Portrayal of Children's Activities in Television Commercials: A Content Analysis, Journal of Business Ethics, vol. 17, no. 14, pp. 1541-1549, 1998.

[28] Protect Them Association: Protégeles/Defensor Del Menor De La Comunidad De Madrid (2006). Childhood Security and Habits of Children in the Use of Mobile Telephone, Study 2005. [Online]. Available: http://www.protegeles.com/telefonia.doc

[29] Red.es (2006). Childhood and Adolescence in the Information Society, Report 2005. [Online]. Available: http://observatorio.red.es/estudios/documentos/infancia tecnologia.pdf

[30] D.L. Roedder, Age differences in children's responses to television advertising: an information-processing approach, Journal of Consumer Research, no. 8, pp. 144-153, 1981

[31] J.C. Sipior, B.T. Ward and N.M. Rongione, Ethics of collecting and using consumer Internet data, Information Systems Management, Winter 2004, pp. 58-66.

[32] Telecommunications Market Commission (2007). Annual Report 2006. [Online]. Available: http://www.cmt.es/es/publicaciones/anexos/IA2006.pdf

[33] R. K. Yin, Case Study Research. Design and Methods, 3rd ed. Applied Social Research Method Series, vol. 5. Sage Publications, 2002. 